University of Nebraska - Lincoln

DigitalCommons@University of Nebraska - Lincoln

Faculty Publications: Department of

Entomology

Entomology, Department of

$2-1987$

Plant Age Effect on the Level of Resistance of Rice "IR36" to the Green Leafhopper, Nephotettix virescens (Distant) and Rice Tungro Virus

H. R. Rapusas

E. A. Heinrichs

Follow this and additional works at: https://digitalcommons.unl.edu/entomologyfacpub

Part of the Agriculture Commons, and the Entomology Commons

This Article is brought to you for free and open access by the Entomology, Department of at

DigitalCommons@University of Nebraska - Lincoln. It has been accepted for inclusion in Faculty Publications:

Department of Entomology by an authorized administrator of DigitalCommons@University of Nebraska - Lincoln. 

permission.

Submitted March 10, 1986; accepted October 6, 1986; published February 1, 1987.

\title{
Plant Age Effect on the Level of Resistance of Rice "IR36" to the Green Leafhopper, Nephotettix virescens (Distant) and Rice Tungro Virus
}

\author{
H. R. Rapusas and E. A. Heinrichs
}

Department of Entomology, International Rice Research Institute, Manila, Philippines

\begin{abstract}
Plant age of a moderately resistant rice cultivar, "IR36," had a distinct effect on the level of Nephotettix virescens (Distant) resistance. Plants at $10 \mathrm{~d}$ after sowing (DAS) were preferred over those at 20, 40, or 60 DAS. $N$. virescens survival, growth index, and adult weight were higher on plants 20 DAS than on plants 40,60, or 80 DAS. Although the total amount of honeydew excreted was similar for "IR36" plants of all ages, the reaction of honeydew on filter paper treated with bromocresol green indicated that feeding in the nutrient-rich phloem was highest on the younger plants. Tungro virus transmission was related to extent of phloem feeding, and the percentage of infection was highest on young plants.
\end{abstract}

Keywords: Nephotettix virescens, rice, plant age, tungro virus, resistance

The green leafhopper, Nephotettix virescens (Distant) (Homoptera: Cicadellidae), is an important pest of rice, Oryza sativa L., throughout Asia (Khush 1977) because it is a highly efficient vector of rice tungro virus (Rivera \& Ou 1965). The degree of infection with tungro virus is dependent on a number of factors, including the susceptibility of the cultivar to $N$. virescens, the size of population of viruliferous $N$. virescens, and the age of rice plants at time of inoculation.

Studies by Ling \& Palomar (1966) indicated that incidence and intensity of tungro virus decreased with increasing plant age at the time of inoculation. Because the IR rice cultivars 
so far released are not known to have resistance to tungro virus, there is apparently an increase in level of resistance to the vector, $N$. virescens, with increasing plant age. Rapusas \& Heinrichs (1982a) showed that survival of N. virescens on IR cultivars "IR5" to "IR46" generally decreased with plant age, being lower at 45 and $60 \mathrm{~d}$ after sowing (DAS) than at 15 or 30 DAS.

"IR36" is the most extensively grown rice cultivar in the world (International Rice Research Institute 1983). A survey conducted in 1980 indicated that selection for virulent N. virescens biotypes on "IR36" was not evident at that time (Rapusas \& Heinrichs 1982b). However, recent tests on $N$. virescens cultures collected in rice fields in the Philippines indicate the presence of a biotype virulent on "IR36" (Rapusas \& Heinrichs 1986). Because of the concern for N. virescens biotype selection on "IR36" and the need to develop effective management strategies, a study was conducted to understand better the nature of resistance in "IR36," especially as affected by plant age.

\section{Materials and Methods}

A series of tests was conducted under greenhouse conditions $\left(20-32^{\circ} \mathrm{C},>70 \% \mathrm{RH}\right)$ at the International Rice Research Institute, Los Baños, Philippines. "IR36," a cultivar with moderate resistance to N. virescens (Rapusas \& Heinrichs 1982a), served as the test cultivar, and "Taichung Native 1" ("TN1") as the susceptible check. In all tests, treatments were arranged in a randomized complete block design (RCBD) and treatment means were separated using Duncan's (1951) multiple range test.

\section{N. virescens Preference for "TN1" and "IR36" Plants}

Seeds of "TN1" and "IR36" were sown in rows, in soil, at the center of clay pots. At 20 DAS the plants were thinned, leaving 20 plants per pot.

To determine the preference of $N$. virescens for the cultivars at 20 DAS, a mylar-film cage ( 18 by 18 by $18 \mathrm{~cm}$ ) with nylon mesh windows ( 12 by $12 \mathrm{~cm}$ ) on opposite sides was placed in between one pot each of the two cultivars. The leaves of the plants were held against the nylon mesh windows by a string tied around the cage.

Fifty $N$. virescens adults ( 25 males and 25 females), from a culture reared on "TN1" in the greenhouse for about 50 generations, were placed into the cage through a hole at the top. The hole was then plugged with cotton. Counts of insects on the windows at either side of the cage were made at $30 \mathrm{~min}$, and 1,2, 4, 6, and $8 \mathrm{~h}$ after their introduction into the cage. The experimental units, each consisting of a cage and one pot of each cultivar, were replicated seven times.

\section{N. virescens Preference for "IR36" Extracts}

Extracts were obtained by steam distillation of "IR36" leaves (from 60-d-old plants) and extraction in ether. Leaves were ground with an electric grinder. The ground samples, each weighing $200 \mathrm{~g}$, were steam-distilled for about $4 \mathrm{~h}$. The distillate was extracted with diethy] ether ( $300 \mathrm{ml}$ distillate: $100 \mathrm{ml}$ diethyl ether) by thoroughly shaking the mixture of the two together in a separatory funnel for approximately $5 \mathrm{~min}$. The water layer was discarded while the extract from different samples of "IR36" was pooled in a 500-ml beaker to which 
$100 \mathrm{~g}$ of anhydrous sodium sulfate was added. After the ether had evaporated at ca. $25^{\circ} \mathrm{C}$ to approximately $25 \mathrm{ml}$, the beaker was covered with aluminum foil and left in the fume chamber overnight to allow the anhydrous sodium sulfate to absorb any trace of water from the extract. The extract was further evaporated to $10 \mathrm{ml}$ and decanted into a preweighed vial, which was then covered with perforated aluminum foil and placed in a desiccator. Ether was evaporated under a vacuum, leaving behind a yellowish residue. A 500ppm solution of the extract in acetone was prepared. Treatments consisted of 20-d-old "TN1" plants, of which the leaves were swabbed with cotton saturated with the extract, and "TN1" plants that were untreated.

The plants were assayed as in the previous experiment with untreated "TN1" on one side of the cage and treated "TN1" on the other. Treatments were replicated seven times and arranged in a RCBD.

\section{Plant Age Effect on N. virescens Preference}

Potted plants of "IR36" at 20, 40, 60, and 80 DAS were used. Four pots (one pot for each cage) were randomly arranged opposite each other. The pots with smaller plants were elevated so that the leaves of all the plants were of the same height.

A square mylar-film cage ( 18 by 18 by $18 \mathrm{~cm}$ ) with nylon mesh windows ( 5 by $5 \mathrm{~cm}$ ) on the four lateral sides was placed in the center of the four pots so that the leaves of the plants coincided with the windows. The cage was held in place by a piece of string tied around the plants so that the leaves were held against the nylon mesh windows. Then 1001 -d-old $N$. virescens adults (50 males and 50 females) reared on "TN1" were introduced into the cage. Counts of the insects on the sides associated with each plant age were made at 30 min and 1, 2, 4, 6, and $8 \mathrm{~h}$ after infestation.

Treatments were replicated five times and arranged in a RCBD. One pot of each plant age represented an experimental unit.

\section{N. virescens Adult Female Survival}

Seed of "IR36" was sown at 20-d intervals to have plants at 20, 40, 60, and 80 DAS at the same time. Six-day-old seedlings were transplanted into clay pots $(10 \mathrm{~cm}$ in diameter), five seedlings per pot. Each treatment was replicated 10 times, one pot representing one replication. "TN1" at 30 DAS served as the check.

When the plants reached the desired ages (20,40,60, and 80 DAS) they were pruned to five tillers per pot. Each pot was then enclosed in a mylar-film cage and five pairs of 1-d-old $N$. virescens adults were introduced into each cage. Mortality of female adults was recorded at $1,5,10,15$, and $20 \mathrm{~d}$ after infestation (DAI).

\section{Oviposition and Egg Hatchability}

Procedures were similar to those in the adult female survival experiment. Five pairs (male and female) of 3-d-old $N$. virescens adults were placed in each cage. As soon as nymphs were observed hatching on the plants, they were counted and removed daily. This was done until egg hatching was completed.

When no further nymphs were observed and all adults were dead, the plants were dissected and unhatched eggs were counted. The total number of eggs laid was determined 
by summing the nymphs counted and the unhatched eggs from each pot. Percentage of eggs hatching was computed.

\section{Adult Emergence, Growth Index, and Weight}

Seeds of "IR36" were sown at 20-d intervals in order to obtain plants at ages of 20, 40, 60, and $80 \mathrm{DAS}$ at the same time. Six-day-old seedlings were transplanted in clay pots $(10 \mathrm{~cm}$ in diameter), two seedlings per pot. Ten replications were made, one pot representing one replication. "TN1" plants at 40 DAS served as checks.

When the plants reached the desired ages, the plants in each pot were pruned to one tiller per pot, except for the 20-DAS treatment, which had two tillers because the plants were small. Then each pot was enclosed in a mylar-film cage, and to each cage 10 newly hatched nymphs were introduced. Test insects came from a culture reared on "TN1" in the greenhouse. When adults began to emerge, counting was done daily, and adults that emerged each day were collected, placed in plastic vials, and individually weighed. This procedure was continued until adult emergence was completed or nymphs were dead. The percentage surviving (adult recovery), period of development from first instar to adult, and adult weight were computed. The growth index was calculated as survival (\%)/length of nymph period $(d)$.

\section{Feeding Activity}

Plants of "IR36" at 20, 40, 60, and 80 DAS, and "TN1" at 30 DAS were transplanted in pots at one plant per pot. Ten replications were made per treatment.

A honeydew-collection chamber with filter papers treated with bromocresol green to collect the honeydew excreted by the insect was attached to each plant (Paguia et al. 1980). Two 1-d-old adult $N$. virescens (one male plus one female) were placed in each chamber and allowed to feed for $20 \mathrm{~h}$. Then the filter papers were removed and air-dried. The amount of honeydew excreted was determined by measuring the area of the honeydew spots on the filter papers, and the amount of honeydew excreted was expressed in $\mathrm{mm}^{2}$. Honeydew spots with a blue color were measured separately to determine the amount of phloem feeding by the insects (Auclair et al. 1981).

\section{Rice Tungro Virus Infection}

"IR36" plants at 10, 20, 40, and 60 DAS, and "TN1" at 20 DAS were planted singly in pots enclosed in mylar-film cages. Treatments were replicated 10 times, five plants serving as a replicate. Two viruliferous $N$. virescens adults were introduced into each cage and after $24 \mathrm{~h}$ of feeding (virus inoculation), they were removed. The plants were left in the greenhouse and at $21 \mathrm{~d}$ after virus inoculation, tungro-infected plants were counted and percentage of tungro virus infection computed. 


\section{Results}

\section{N. virescens Preference}

N. virescens had a distinct preference for "TN1" plants over "IR36" (Fig. 1). This difference was obvious at $1 \mathrm{~h}$ after infestation and increased in subsequent observations. At $8 \mathrm{~h}$ after infestation, there were 4 -fold as many N. virescens on "TN1" as on "IR36."

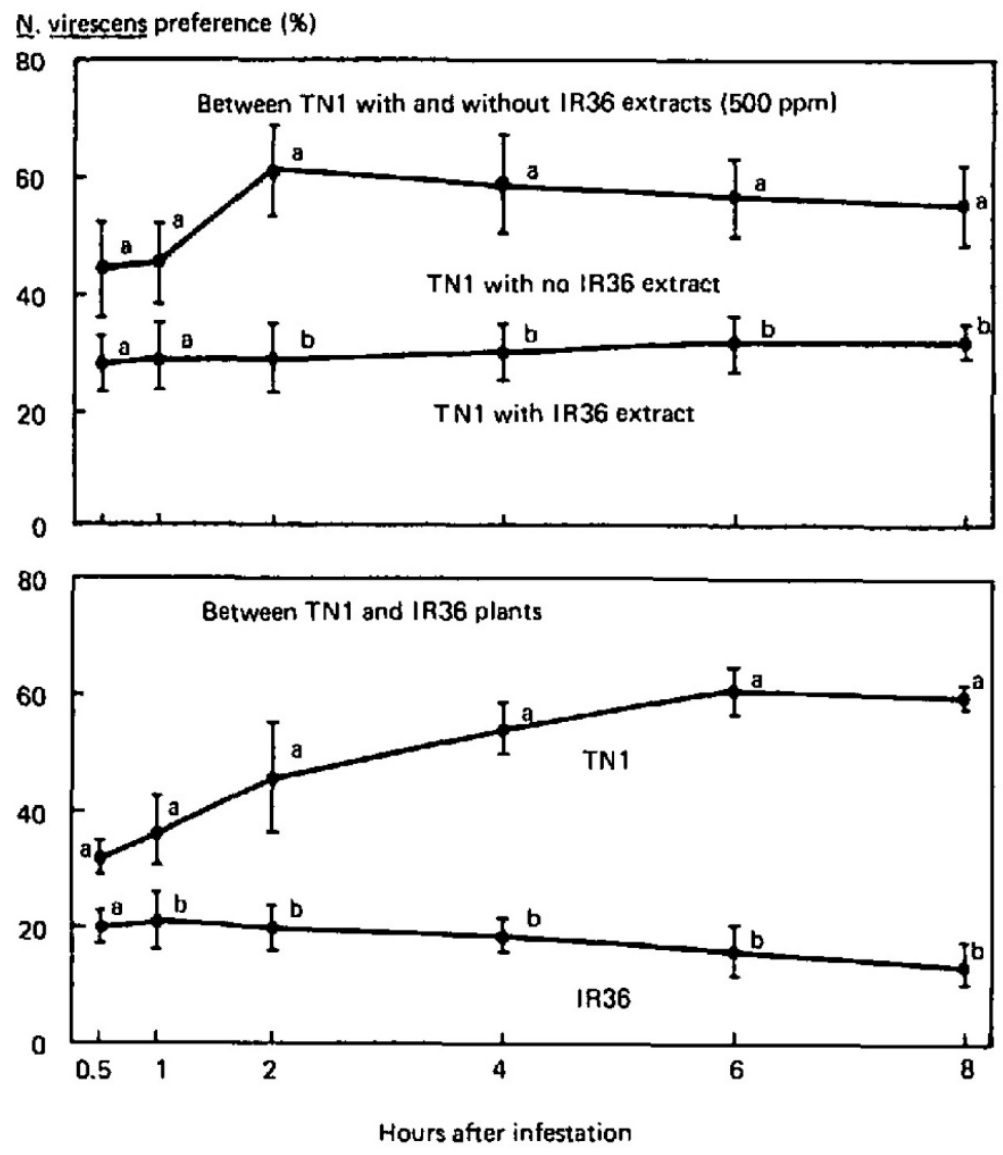

Figure 1. Percentage of N. virescens on rice cultivar "TN1" with and without treatment with "IR36" extracts (upper) and on "TN1" and "IR36" plants (lower) at various intervals after infestation. Points with the same letter at each observation are not significantly different ( $P<0.05$; Duncan's [1951] multiple range test). Data are an average of three plant ages $(20,40$, and $60 \mathrm{DAS})$. Bars indicate $\pm 1 \mathrm{SD}$.

Steam-distilled extracts of "IR36," when applied on "TN1" plants, attracted fewer N. virescens than untreated "TN1" plants (Fig. 1). The difference between the two treatments was significant $(P<0.05)$ beginning $2 \mathrm{~h}$ after infestation and continuing to $8 \mathrm{~h}$ when the test was terminated. 
Plant age of "IR36" had a distinct effect on preference of N. virescens (Fig. 2). Significant $(P<0.05)$ differences among treatments occurred $30 \mathrm{~min}$ after infestation and continued to the end of the test $8 \mathrm{~h}$ after infestation. Preference decreased with plant age up to 40 DAS.

N. virescens preference $(\%)$ on IR36 at different plant ages

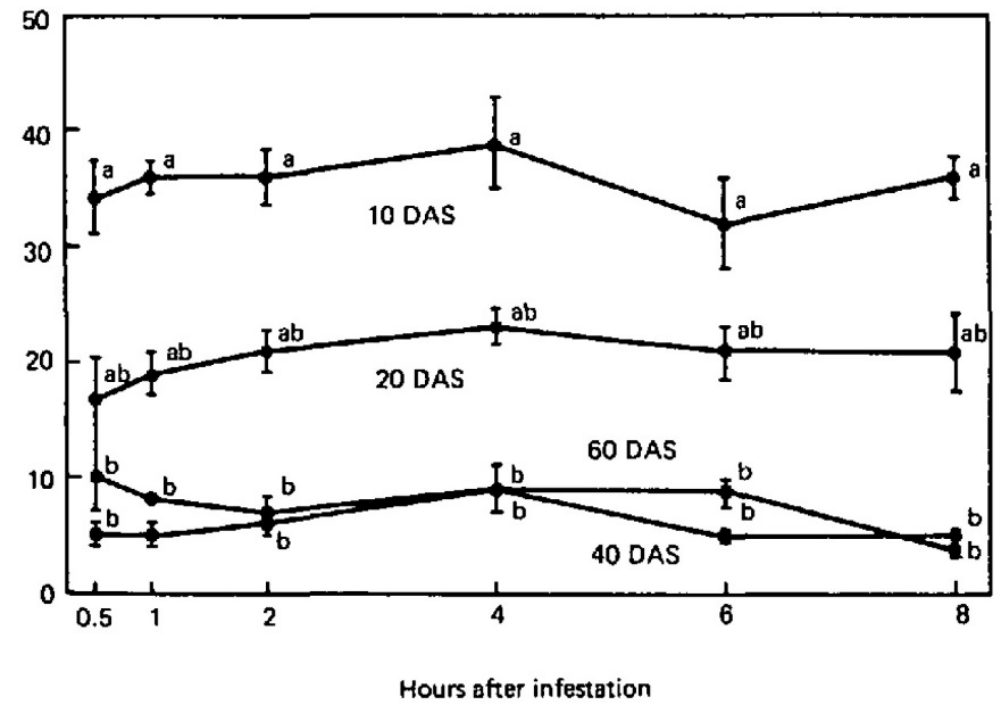

Figure 2. Percentage of $N$. virescens on rice cultivar "IR36" at four plant ages (DAS) at various intervals after infestation. Points with the same letter at each observation are not significantly different $(P<0.05$; Duncan's [1951] multiple range test). Bars indicate \pm 1 SD.

\section{Survival and Development}

Significant $(P<0.05)$ differences in $N$. virescens survival on plants of different ages first occurred $5 \mathrm{~d}$ after infestation (Table 1). Survival was highest on 20-DAS "IR36" plants, not being significantly $(P<0.05)$ different from that of susceptible "TN1." There were differences in survival on "IR36" plants 40, 60, and 80 DAS. By 15 DAI, there was no difference among "IR36" ages.

Table 1. N. virescens adult female survival (\%) on "IR36" and “TN1" plants

\begin{tabular}{lcccccc}
\hline & Plant age & \multicolumn{5}{c}{ DAI $^{\mathrm{a}}$} \\
\cline { 3 - 7 } Cultivar & (DAS) & 1 & 5 & 10 & 15 & 20 \\
\hline "IR36" & 20 & $98 \pm 6 \mathrm{a}$ & $88 \pm 14 \mathrm{ab}$ & $80 \pm 16 \mathrm{a}$ & $40 \pm 18 \mathrm{ab}$ & $12 \pm 10 \mathrm{~b}$ \\
& 40 & $98 \pm 6 \mathrm{a}$ & $72 \pm 14 \mathrm{c}$ & $56 \pm 18 \mathrm{c}$ & $42 \pm 18 \mathrm{ab}$ & $12 \pm 10 \mathrm{~b}$ \\
& 60 & $98 \pm 6 \mathrm{a}$ & $74 \pm 13 \mathrm{bc}$ & $60 \pm 19 \mathrm{bc}$ & $30 \pm 14 \mathrm{~b}$ & $14 \pm 10 \mathrm{~b}$ \\
& 80 & $98 \pm 10 \mathrm{a}$ & $68 \pm 10 \mathrm{c}$ & $52 \pm 12 \mathrm{c}$ & $36 \pm 16 \mathrm{ab}$ & $20 \pm 9 \mathrm{~b}$ \\
"TN1" & 30 & $100 \pm 0 \mathrm{a}$ & $90 \pm 10 \mathrm{a}$ & $74 \pm 16 \mathrm{ab}$ & $50 \pm 19 \mathrm{a}$ & $36 \pm 8 \mathrm{a}$ \\
\hline
\end{tabular}

a. Means in a column followed by the same letter are not significantly different $(P<0.05$; Duncan's [1951] multiple range test). Means \pm SD based on 10 replications. 
$N$. virescens confined on "TN1" plants laid twice as many eggs as those on "IR36" (Table 2). However, there were no differences in oviposition rate among the four ages of "IR36." Percentage of hatchable $N$. virescens eggs was high on both cultivars and was not affected by age of "IR36."

Table 2. Oviposition rate and egg hatchability

\begin{tabular}{lccc}
\hline Cultivar & Plant age (DAS) & No. eggs laid/female & Egg hatchability (\%) $^{\mathrm{a}}$ \\
\hline "IR36" & 20 & $51 \pm 8 \mathrm{~b}$ & $97 \pm 2 \mathrm{a}$ \\
& 40 & $58 \pm 15 \mathrm{~b}$ & $93 \pm 2 \mathrm{a}$ \\
& 60 & $42 \pm 14 \mathrm{~b}$ & $97 \pm 2 \mathrm{a}$ \\
& 80 & $40 \pm 11 \mathrm{~b}$ & $99 \pm 1 \mathrm{a}$ \\
"TN1" & 30 & $122 \pm 17 \mathrm{a}$ & $96 \pm 4 \mathrm{a}$ \\
\hline
\end{tabular}

a. Means in a column followed by the same letter are not significantly different $(P<0.05$; Duncan's [1951] multiple range test). Means \pm SD based on 10 replications.

All ages of "IR36" decreased survival of $N$. virescens nymphs to the adult stage as compared with "TN1" (Table 3). Adult emergence was lowest on "IR36" plants 40 DAS, being only $8 \%$, compared with a range of $42-58 \%$ on plants 20,60 , and 80 DAS.

The growth index was lower on the "IR36" plants than on "TN1" (Table 3). The growth index ranged from 0.4 on the 40-DAS "IR36" plants to 3.0 on the 20-DAS plants.

Weight of adult males and females was significantly $(P<0.05)$ lower on all "IR36" ages than when reared on "TN1" (Table 3). Female weight was significantly lower on "IR36" plants 40 DAS than on "IR36" plants 20, 60, and 80 DAS.

Table 3. Adult emergence, growth index, and weight

\begin{tabular}{lccccc}
\hline & \multirow{2}{*}{$\begin{array}{c}\text { Plant age } \\
\text { Cultivar }\end{array}$} & No. adults & & \multicolumn{2}{c}{ Wt (mg) } \\
\cline { 5 - 6 } (DAS) & emerged (\%) & Growth index & Male & Female \\
\hline "IR36" & 20 & $56 \pm 23 \mathrm{~b}$ & $3.0 \pm 1.8 \mathrm{~b}$ & $1.693 \pm 0.4 \mathrm{~b}$ & $2.733 \pm 0.3 \mathrm{bc}$ \\
& 40 & $8 \pm 10 \mathrm{c}$ & $0.4 \pm 0.5 \mathrm{c}$ & $1.723 \pm 0.3 \mathrm{~b}$ & $1.955 \pm 0.5 \mathrm{~d}$ \\
& 60 & $42 \pm 11 \mathrm{~b}$ & $2.0 \pm 0.7 \mathrm{~b}$ & $1.957 \pm 0.3 \mathrm{~b}$ & $2.904 \pm 0.5 \mathrm{~b}$ \\
& 80 & $58 \pm 24 \mathrm{~b}$ & $2.5 \pm 1.0 \mathrm{~b}$ & $1.627 \pm 0.3 \mathrm{~b}$ & $2.622 \pm 0.4 \mathrm{c}$ \\
"TN1" & 30 & $92 \pm 14 \mathrm{a}$ & $5.6 \pm 0.9 \mathrm{a}$ & $2.454 \pm 0.1 \mathrm{a}$ & $3.800 \pm 0.3 \mathrm{a}$ \\
\hline
\end{tabular}

a. Means in a column followed by the same letter are not significantly different $(P<0.05$; Duncan's [1951] multiple range test). Means \pm SD based on 10 replications with 10 nymphs initially per replication.

b. Survival (\%)/length of nymph period (days).

\section{Feeding Activity and Virus Infection}

Feeding activity as based on honeydew excretion was similar on all treatments (Table 4). However, the area of honeydew spots, which had a basic reaction when treated with bromocresol green, was highest in the "TN1" treatment, indicating a greater extent of phloem sap removal. Among the four "IR36" treatments, area of basic honeydew spots was 2- to 3 -fold higher on plants 20 DAS than on the other ages. 
Table 4. Honeydew excretion by N. virescens on "IR36" and "TN1" plants

\begin{tabular}{lccc}
\hline Cultivar & Plant age (DAS) & $\begin{array}{c}\text { Total area of honeydew } \\
\text { spots }\left(\mathrm{mm}^{2}\right)^{\mathrm{a}}\end{array}$ & $\begin{array}{c}\text { Area of blue honeydew } \\
\text { spots }\left(\mathrm{mm}^{2}\right)^{\mathrm{ab}}\end{array}$ \\
\hline "IR36" & 20 & $462 \pm 107 \mathrm{a}$ & $13 \pm 4 \mathrm{~b}$ \\
& 40 & $567 \pm 121 \mathrm{a}$ & $6 \pm 4 \mathrm{c}$ \\
& 60 & $552 \pm 135 \mathrm{a}$ & $4 \pm 3 \mathrm{c}$ \\
& 80 & $440 \pm 90 \mathrm{a}$ & $4 \pm 3 \mathrm{c}$ \\
& 30 & $437 \pm 129 \mathrm{a}$ & $106 \pm 32 \mathrm{a}$ \\
\hline
\end{tabular}

a. Means in a column followed by the same letter are not significantly different $(P<0.05$; Duncan's [1951] multiple range test). Means \pm SD based on 10 replications with 10 insects per replication.

b. Blue spots from the reaction of honeydew on bromocresol green-treated filter paper indicated honeydew taken from the phloem tissue of the plants.

Percentages of tungro virus-infected plants decreased with an increase in age of "IR36" (Fig. 3).

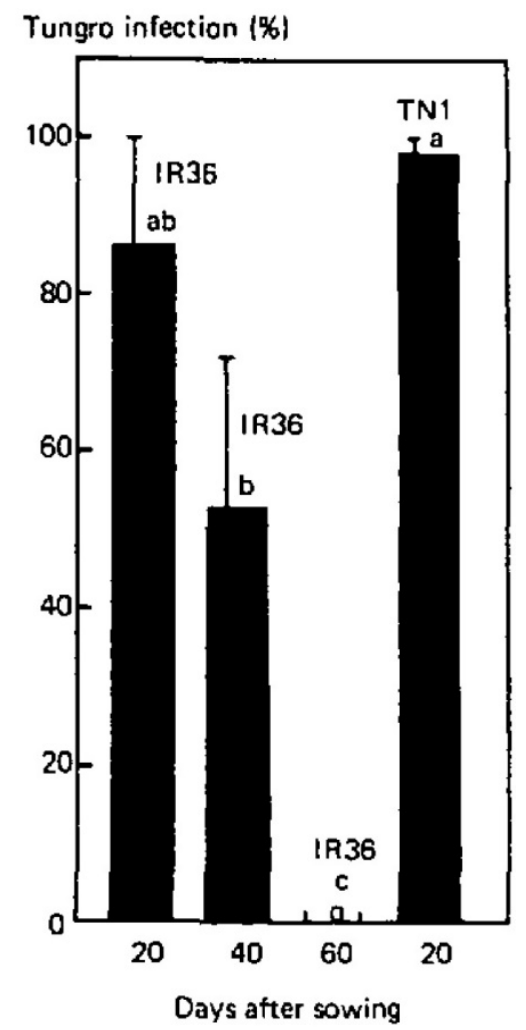

Figure 3. Percentage of rice "IR36" plants infected with tungro virus when two viruliferous $N$. virescens were released per plant of four plant ages (DAS) and susceptible "TN1" infested 20 DAS. Columns with the same letter are not significantly different $(P<0.05$; [1951] multiple range test). Bars indicate \pm 1 SD. 


\section{Discussion}

The various tests conducted confirmed the moderate level of $N$. virescens resistance of "IR36." The level of resistance, however, was highly dependent on plant age, with the youngest plants (10-20 DAS) being least resistant.

Nonpreference was one of the mechanisms causing resistance to $N$. virescens. The youngest plants (10 DAS) were distinctly most preferred by $N$. virescens. Nonpreference appears to be caused by chemicals that are extracted from "IR36" in the steam-distillation process because the application of the "IR36" extract to a susceptible cultivar, "TN1," significantly decreased the preference of $N$. virescens. In addition to a low level of nonpreference, $N$. virescens survival and growth was highest on the young "IR36" plants.

The low level of resistance in the young "IR36" plants was evident in the ability of $N$. virescens to remove greater amounts of phloem sap from these plants. Previous studies have shown that $N$. virescens feeds primarily in the xylem of resistant cultivars but feeds in both the xylem and nutrient-rich phloem of susceptible cultivars (Auclair et al. 1981).

Ling \& Palomar (1966) demonstrated a decreasing incidence of tungro virus with an increase in plant age. They attributed this to an increase in the level of tolerance. The high incidence of tungro virus in young (10-20 DAS) "IR36" plants may be due to a combined effect of a lack of tolerance to the virus and a low level of resistance to the vector. The amount that each factor contributes is not known but it is evident that the ability for greater removal of phloem sap from plants 20 DAS by $N$. virescens is conducive to increased tungro incidence (Heinrichs \& Rapusas 1984).

Because of the low level of resistance to the vector in young plants, management of tungro virus requires control of vectors in the nursery (10-20 DAS) and in the field for about 40 days after transplanting (60 DAS). Because of this, high-yielding cultivars with high levels of $N$. virescens resistance at all plant ages have been developed and such cultivars will probably replace where tungro virus pressure is severe.

\section{References Cited}

Auclair, J. L., E. Baldos \& E. A. Heinrichs. 1981. Biochemical evidence for the feeding sites of the leafhopper, Nephotettix virescens, within susceptible and resistant rice plants. Insect Sci. Appl. 3: 29-40.

Duncan, D. B. 1951. A significance test for differences between ranked treatments in an analysis of variance. Va. J. Sci. 2: 171-189.

Heinrichs, E. A. \& H. R. Rapusas. 1984. Feeding, development and tungo virus transmission by the green leafhopper, Nephotettix virescens (Distant) (Homoptera: Cicadellidae), after selection on resistant rice cultivars. Entomol. 13: 1074-1078.

International Rice Research Institute. 1983. “IR36," the world's most popular rice. International Rice Research Institute, Los Baños, Philippines.

Khush, G. S. 1977. Disease and insect resistance in rice. Adv. Agron. 29: 265-341.

Ling, K. C. \& M. K. Palomar. 1966. Studies on rice plants infected with the tungro virus at different ages. Philipp. Agric. 50: 165-177. 
Paguia, P., M. D. Pathak \& E. A. Heinrichs. 1980. Honeydew excretion measurement techniques for determining differential feeding activity of biotypes of Nilaparvata lugens on rice varieties. J. Econ. Entomol. 73: 35-40.

Rapusas, H. R. \& E. A. Heinrichs. 1982a. Plant age and levels of resistance to green leafhopper, Nephotettix virescens (Distant), and tungro virus in rice varieties. Crop Prot. 1: 91-98.

Rapusas, H. R. \& E. A. Heinrichs. 1982b. Comparative virulence of 15 Philippine cultures of green leafhopper, Nephotettix virescens (Distant), on selected varieties. Philipp. Entomol. 5: 213-226.

Rapusas, H. R. \& E. A. Heinrichs. 1986. Virulence of green leafhopper (GLH) colonies from Luzon, Philippines, on IR36 and IR42. Int. Rice Res. Newsl. 11(1): 15.

Rivera, C. T. \& S. H. Ou. 1965. Leafhopper transmission of "tungro" disease of rice. Plant Dis. Rep. 49: 127-131. 